\begin{tabular}{|c|c|c|c|c|c|c|}
\hline \multirow{4}{*}{ Impact Factor: } & ISRA (India) & $=3.117$ & SIS (USA) & $=0.912$ & ICV (Poland) & $=6.630$ \\
\hline & ISI (Dubai, UAE & $=0.829$ & РИНЦ (Russia) & $=0.156$ & PIF (India) & $=1.940$ \\
\hline & GIF (Australia) & $=0.564$ & ESJI (KZ) & $=8.716$ & IBI (India) & $=4.260$ \\
\hline & JIF & $=1.500$ & SJIF (Morocco) & $=5.667$ & OAJI (USA) & $=0.350$ \\
\hline
\end{tabular}

\begin{tabular}{|c|c|}
\hline $\begin{array}{l}\text { SOI: } \frac{1.1 / \mathrm{TA}}{} \\
\text { International Sc } \\
\text { Theoretical } \boldsymbol{\&} A\end{array}$ & $\begin{array}{l}\text { IS DOI: } 10.15863 / \mathrm{TAS} \\
\text { cientific Journal } \\
\text { Applied Science }\end{array}$ \\
\hline p-ISSN: 2308-4944 (print) & e-ISSN: 2409-0085 (online) \\
\hline Year: $2019 \quad$ Issue: 06 & Volume: 74 \\
\hline Published: 20.06 .2019 & http://T-Science.org \\
\hline
\end{tabular}

QR - Issue

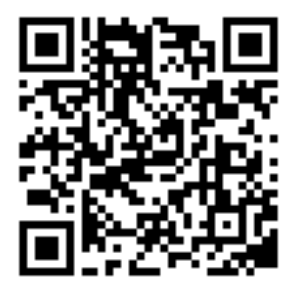

Elizaveta Mihailovna Bordenova

Peter the Great St.Petersburg Polytechnic University student

borden.em@yandex.ru

Vadim Andreevich Kozhevnikov

Peter the Great St.Petersburg Polytechnic University

Senior Lecturer

vadim.kozhevnikov@gmail.com

\title{
RESEARCH OF DEPENDENCIES OF STUDENT ACTIVITY AS A DONOR
}

Abstract: This study refers to spheres of data analysis and machine learning. The study was made to find whether there are any dependencies between donations and student associations and other factors. At the beginning of the article the features of donors were found and the classifier defining the type of activity of the donor was designed. Then, the data were collected and analyzed, the model of the donor activity predictor was trained. The predictor's work was tested on new data. The article also describes the results and the analysis of the obtained dependencies.

Key words: blood donation, machine learning, $R$ programming language.

Language: English

Citation: Bordenova, E. M., \& Kozhevnikov, V. A. (2019). Research of dependencies of student activity as a donor. ISJ Theoretical \& Applied Science, 06 (74), 328-339.

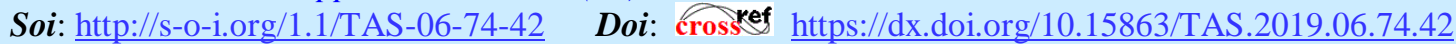

\section{Introduction}

Despite the enormous development of medicine in recent years, there are still a large number of people in need of blood transfusions. Blood donation around the world is one of the most important problems that requires constant attention. In addition, there is even a special holiday, which, incidentally, took place just recently on June 14.

World Blood Donor Day is a special day commemorating non-remunerated blood donors. The main purpose of such a celebration is to raise public awareness of the need for blood donation and to promote respect for donors. [1]

Various campaigns were also created to attract new people and support regular donors. One of them was the "Donor Day" at St.Petersburg Polytechnic University. [2]

This action has been in existence since 2015 . However, it has changed a lot since its inception. In the beginning, it was a small action for a small group of people up to 100 people, and it was held once a year. Currently, the campaign is held twice a year (spring and autumn) for 2 weeks, during which more than 1000 people take part. In addition, there are separate visits once a month.

As you can see, the terms of the campaign have changed a lot. First of all, it affected the need to modernize the information system of donor accounting. To date, the new system has already been designed and is being developed.

In the process of modifying the information system, other interesting ideas emerged. The "Donor Day" campaign is developing, not standing still and not lagging behind the technical progress. In this regard, it was decided to introduce machine learning into the donor information system.

What is the point? Every year and every action we receive a lot of new donors. New people are always good, but what percentage of them will come back at least one again? But in order for blood to help people, donors need to give blood again after six months, and in the same blood transfusion unit.

This condition is due to the fact that when donated blood is divided into components, of which the blood plasma must be quarantined in six months. When the donor comes back, his blood is checked. If 


\begin{tabular}{llllll} 
& ISRA (India) $=\mathbf{3 . 1 1 7}$ & SIS (USA) & $=\mathbf{0 . 9 1 2}$ & ICV (Poland) & $=\mathbf{6 . 6 3 0}$ \\
Impact Factor: & ISI (Dubai, UAE) $=\mathbf{0 . 8 2 9}$ & PUHL (Russia) $=\mathbf{0 . 1 5 6}$ & PIF (India) & $=\mathbf{1 . 9 4 0}$ \\
& GIF (Australia) $=\mathbf{0 . 5 6 4}$ & ESJI (KZ) & $=\mathbf{8 . 7 1 6}$ & IBI (India) & $=\mathbf{4 . 2 6 0}$ \\
& JIF & $\mathbf{1 . 5 0 0}$ & SJIF (Morocco) $=\mathbf{5 . 6 6 7}$ & OAJI (USA) & $\mathbf{0 . 3 5 0}$ \\
\hline
\end{tabular}

no infections are detected, the first portion of its frozen plasma is sent to medical organizations for transfusion to patients, and the fresh is laid on the quarantine. [3] Yes, there is also an option to come to the ward and take a routine blood test to check for infections and send a previous portion of the plasma to help people. Are there many responsible people among the one-day donors who think about it? Otherwise, if the donor does not come, the old plasma is simply thrown away and all efforts to help people were in vain. In addition, these donors were wasting the time of doctors, volunteers and maybe more responsible and active donors.

Thus, the problem of inactive donors was identified. In order to simplify the work of the volunteers of the campaign, a system of donor activity prediction was invented, which will be based on machine learning.

\section{The purpose of the article}

The purpose of this article is to study the activity of students of St.Petersburg Polytechnic University as donors. We will look for the dependence of donor activity on various factors. After that we will be able to obtain a unique predictor of donor activity based on the data from the study.

\section{The main objectives are as follows}

Let us identify the main tasks that need to be performed to achieve the goal:

- To think about and develop indicators, i.e. what the donor's activity may depend on;

- To formulate a hypothesis based on these signs;

- To develop a criterion for determining the degree of donor activity;

- To collect the necessary test sample to teach the predictor model by online survey of students;

- To analyze the data collected and perform the necessary calculations;

- To develop and run a model of the forecast tree on a test sample with the addition of a donor activity class;

- To study of the results, study of the obtained dependencies on the tree of predictions;

- To check of the trained classifier model on the test sample;

- Summing up our research.

\section{Signs for the predictor model}

To begin with, let's determine the dependencies on which factors we will study. Our target audience is students of St.Petersburg State Polytechnic University. Accordingly, the main signs will be:

- Gender;

- Presence or absence of work;
- Course number (from 1 to 6 is both bachelor's and specialist's degrees, and master's degrees);

- Accommodation: in a dormitory, rented apartment/room or with relatives;

- Whether the student volunteers for the Donor Day campaign and how active they are at the moment.

Why such criteria? It is suggested that students who have jobs are less likely to be active donors because they are more busy and less in need of money (donors receive some material payment for food and rehabilitation for donating blood). Also, there is a fairly common theory that guys living in dormitories are more active and more likely to need money.

In addition, it is planned to consider the dependence on gender and course number. The highest peak of student activity usually falls on the course 3-4. And additional dependence of the donor's activity on whether he or she is a member of the volunteer group of the "Donor's Day" action and whether he or she leads an active life in it as a volunteer.

The dependence of donor activity on student activity will be investigated separately. The concept of student activity includes participation in various student associations of the university.

Now there are 18 such associations. [4] In order not to single out any of them and not to be subjective, we will check each of them separately.

The list of student associations of St. Petersburg State Polytechnic University:

1. Profsoyuznaya organization;

2. Student news agency SPbPU;

3. Student departments;

4. Center for Patriotic Education of Youth "Motherland";

5. VIC "Our Polytech";

6. Student club;

7. Energy club;

8. Adapters;

9. StudSoviet;

10. Polytechnic Sports Club;

11. Cultural-Educational Center Harmony SPbPU;

12. The Youth Construction and Technology Bureau;

13. YESLAB Student Culinary Organization;

14. Economic Club;

15. Fablab;

16. Volunteer Center of St. Petersburg Polytechnic University "With a Good Heart";

17. Student Scientific Society;

18. Student Engineering Society (SSE).

\section{Hypotheses of research}

Before we do any research, we'll isolate the main hypotheses. They have already been partially listed 


\begin{tabular}{llllll} 
& ISRA (India) $=\mathbf{3 . 1 1 7}$ & SIS (USA) $=\mathbf{0 . 9 1 2}$ & ICV (Poland) & $\mathbf{= 6 . 6 3 0}$ \\
Impact Factor: & ISI (Dubai, UAE) $=\mathbf{0 . 8 2 9}$ & PUHЦ (Russia) $=\mathbf{0 . 1 5 6}$ & PIF (India) & $=\mathbf{1 . 9 4 0}$ \\
& GIF (Australia) $=\mathbf{0 . 5 6 4}$ & ESJI (KZ) & $\mathbf{8 . 7 1 6}$ & IBI (India) & $=\mathbf{4 . 2 6 0}$ \\
& JIF & $\mathbf{1 . 5 0 0}$ & SJIF (Morocco) $=\mathbf{5 . 6 6 7}$ & OAJI (USA) & $\mathbf{0 . 3 5 0}$ \\
\hline
\end{tabular}

above, but we will compile and combine them into one convenient list:

- Students who are unemployed or from dormitories are more likely to become active donors;

- The peak of activity as a donor is 2-3 years;

- A high percentage of active donors should be among the currently active volunteers for Donor Day;

- The higher the student activity of a person, the more active he or she is as a donor;

- A high percentage of active donors will be among student departments representatives. Since the action was created by the student departments and started with the departure of SPbPU, where the fighter of the construction student department "Orion" Alexander Borovov won a grant to create the action [5];

- A fairly high percentage of donor activity is expected among adapters. Adapters even have their own special day and day of travel during the action, when they travel together and together as a team.

- Among other student associations, no strong donor activity is expected anymore.

Thus, we have received a number of hypotheses. Obviously, some of them may not be fulfilled. However, a negative result for us will also be a result and an indicator of the lack of correlation between a particular factor and the donor's activity.

\section{Criterion for determining the donor's activity} class

In order to place students in a class of active donors in the future, it is necessary to find out how to determine the degree of their activity.

The easiest way to assess activity is by the number of blood donations. The more blood donations then the more active the donor is. But this is not the ideal method. The program will consider a donor who donated 4 times in 1 or even 2 years as active as a donor who donated 4 times in 5 years. Obviously, this is not an objective assessment and we need to consider how many years the donor has already donated blood.

Let's remember that it is possible to give blood to women 4 times a year according to the norms, and to men 5 times a year [6]. From here we can easily find the maximum possible number of blood donations for $\mathrm{N}$ years for men and women. Let's combine everything into a single formula, indicating the sex of the person by " $G$ " (Gender). If the student is male, $\mathrm{G}=1$; if the woman is female, $\mathrm{G}=0$.

We get the formula: $(G+4) * N$ is the maximum possible number of blood donations. From this we can conclude that it is necessary for the test sample to find out from the students their number of blood donations. Knowing the number of blood donations, we can determine the percentage of donor activity. Let's mark the number of blood donations with the letter " $K$ ". Then we have a new formula:

$$
\frac{K}{(G+4) * N} * 100 \%
$$

However, let's discuss that the formula finds a percentage of the maximum number of blood donations. There are very few donors who would donate blood 4-5 times a year in our campaign. Accordingly, in order to determine the type of donor activity, one should take into account not only the high percentage, but also how many people have the same number of people and how high this number is among other students.

But that's not all. This formula has a significant disadvantage. Those new donors who have donated blood only once this year will receive their $20-25 \%$ of activity, which is not so little, especially if we take into account that the majority of them will not come back again in the end. We cannot discard the data because such people are an important part of our research. What should we do?

At that time, we decided to combine two ways of determining the donor's activity and make an average estimate. In other words, we start by taking the number of blood donations separately and giving them a category from 0 to 4 :

0 . Not the donor (never once);

1. Inactive or novice donor (made a donation once);

2. Normal (2-3 times);

3. Active (4-7 times);

4. Permanent (8 times and more).

Then we separately calculate the percentage of donor activity taking into account the number of years. The results are then similarly classified in a category from 0 to 4:

0 . Not the donor (he was never a donor);

1. Inactive or novice donor $(0 \%-20 \%)$;

2. Normal (20\%-40\%);

3. Active $(40 \%-60 \%)$

4. Permanent (over 60\%).

Then we find the arithmetic mean between the two criteria, rounding it up to the whole according to the laws of arithmetic. Thus, we have obtained a scheme for determining the class of donor activity. The donor's activity class may be between 0 and 4 as in the previous two criteria.

Creating a questionnaire and interviewing students

We have thought through all the features and classifier of the predictor, so we can move on to the creation of a questionnaire and survey of students.

This questionnaire is completely anonymous. It is divided into 3 parts:

1. Basic information: gender, course, work, accommodation, participation in the action as a volunteer. 


\begin{tabular}{llllll} 
& ISRA (India) $=\mathbf{3 . 1 1 7}$ & SIS (USA) $=\mathbf{0 . 9 1 2}$ & ICV (Poland) & $\mathbf{= 6 . 6 3 0}$ \\
Impact Factor: & ISI (Dubai, UAE) $=\mathbf{0 . 8 2 9}$ & PUHЦ (Russia) $=\mathbf{0 . 1 5 6}$ & PIF (India) & $=\mathbf{1 . 9 4 0}$ \\
& GIF (Australia) $=\mathbf{0 . 5 6 4}$ & ESJI (KZ) & $\mathbf{8 . 7 1 6}$ & IBI (India) & $=\mathbf{4 . 2 6 0}$ \\
& JIF & $\mathbf{1 . 5 0 0}$ & SJIF (Morocco) $=\mathbf{5 . 6 6 7}$ & OAJI (USA) & $\mathbf{0 . 3 5 0}$ \\
\hline
\end{tabular}

2. All student associations of St. Petersburg State Polytechnic University. For each of them there are 3 options: standing, consisting or not standing.

3. Donor information: how many years the student has been donating blood.

At the same time, a person enters the number of blood donors manually (if he or she has was never a donor, he or she simply enters "0"), and for the number of years he or she is offered the following options, taking into account that the action in the university exists only since 2015 :

- Less than six months;

- From six months to a year;
- Two years;

- Three years;

- Four years;

- Five years;

- Six years or more.

Thanks to this separation, we will also be able to better distinguish between new donors, which is important for the study.

The questionnaire was created in Google forms in Russian, as it is more effective to collect results from Russian students. Here are fragments of the questionnaire.

General information:

\section{Исследование активности доноров \\ от различных факторов}

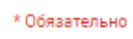

\section{Основная информация}

Мы исследуем зависимость вашей активности как донора от различных факторов. Позтому для начала просьба ответить на общие вопросы.

Пол *

Мужской

Женский

Работа *

Есть

Нет

Проживание *

Живу с родственниками

Снимаю комнату/квартиру

Живу в общаге

Kypc *

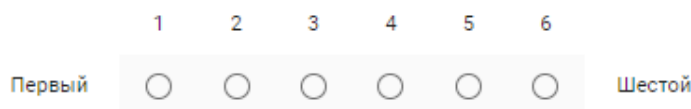

Волонтер Дня донора *

Да, активный сейчас

Да, уже не активный

Нет

Student activity:

Figure 1- Questionnaire. General information 


\begin{tabular}{llllll} 
& ISRA (India) $=\mathbf{3 . 1 1 7}$ & SIS (USA) & $=\mathbf{0 . 9 1 2}$ & ICV (Poland) & $=\mathbf{6 . 6 3 0}$ \\
Impact Factor: & ISI (Dubai, UAE) $=\mathbf{0 . 8 2 9}$ & PUHL (Russia) $=\mathbf{0 . 1 5 6}$ & PIF (India) & $=\mathbf{1 . 9 4 0}$ \\
& GIF (Australia) $=\mathbf{0 . 5 6 4}$ & ESJI (KZ) & $=\mathbf{8 . 7 1 6}$ & IBI (India) & $=\mathbf{4 . 2 6 0}$ \\
& JIF & $\mathbf{1 . 5 0 0}$ & SJIF (Morocco) $=\mathbf{5 . 6 6 7}$ & OAJI (USA) & $\mathbf{0 . 3 5 0}$ \\
\hline
\end{tabular}

\section{Студенческая активность}

Основным фактором для исследования была выбрана студенческая активность. Перед вами список всех студенческих объединений, которые есть в СПбпу. Укажите, состоите ли вы гдениибудь или нет.

Профсоюзная организация *

состою

Состоял(a)

Не состою

Студенческий клуб *

состою

Состоял(а)

Не состою

Студенческие отряды *

состою

Состоял(а)

Не состою

Адаптеры *

Состою

Состоял(а)

Hе состою

Студенческое инженереное общество (Best) *

Состою

Состоял(a)

Не состою

Donor information:

Figure 2 - Questionnaire. Student activity

\begin{tabular}{|c|c|c|c|c|c|c|c|c|c|}
\hline H & 1 & $\mathrm{~J}$ & $\mathrm{k}$ & $\mathrm{L}$ & M & $\mathrm{N}$ & $\circ$ & $\mathrm{P}$ & \\
\hline Курс & Course & Волонтер Дня донора & Volonter & Группа крови & $\begin{array}{c}\text { Профсоюзная } \\
\text { организация }\end{array}$ & st1 & Студенческий клуб & st2 2 & \\
\hline 4 & & 4 Да, активный сейчас & & $22+$ & Состою & & 2 Не состою & & 0 \\
\hline 4 & & 4 Нет & & $03+$ & Не состою & & 0 Не состою & & 0 \\
\hline 4 & & 4 Да, активный сейчас & & $23-$ & Состоял(a) & & 1 Не состою & & 0 \\
\hline 3 & & 3 Нет & & 0 не знаю & Состою & & 2 Не состою & & 0 \\
\hline 2 & & 2 Да, активный сейчас & & $21-$ & Состою & & 2 Не состою & & 0 \\
\hline 4 & & 4 Нет & & 0 не знаю & Состою & & 2 Не состою & & 0 \\
\hline 4 & & 4 Нет & & $03^{+}$ & Состою & & 2 Не состою & & 0 \\
\hline 5 & & 5 Нет & & $02-$ & Состою & & 2 Не состою & & 0 \\
\hline 4 & & 4 Нет & & 0 не знаю & Не состою & & 0 Не состою & & 0 \\
\hline 4 & & 4 Нет & & $02+$ & Состою & & 2 Состоял(a) & & 1 \\
\hline 2 & & 2 Да, активный сейчас & & $22+$ & Состоял(a) & & 1 Не состою & & 0 \\
\hline 4 & & 4 Нет & & $04+$ & Состоял(a) & & 1 Не состою & & 0 \\
\hline 2 & & 2 Нет & & $02+$ & Состою & & 2 Не состою & & 0 \\
\hline 4 & & 4 Нет & & $04+$ & Состою & & 2 Не состою & & 0 \\
\hline 2 & & 2 Да, уже не активный & & $11+$ & Не состою & & 0 Не состою & & 0 \\
\hline 4 & & 4 Нет & & $02+$ & Не состою & & 0 Не состою & & 0 \\
\hline 4 & & 4 Да, активный сейчас & & $22+$ & Не состою & & 0 Не состою & & 0 \\
\hline 3 & & 3 Нет & & $02+$ & Не состою & & 0 Не состою & & 0 \\
\hline 3 & & 3 Да, уже не активный & & $11+$ & Состою & & 2 Не состою & & 0 \\
\hline 3 & & 3 Да, уже не активный & & $14+$ & Не состою & & 0 Не состою & & 0 \\
\hline 2 & & 2 Да, уже не активный & & 1 не знаю & Состою & & 2 Не состою & & 0 \\
\hline 3 & & 3 Да, уже не активный & & $11+$ & Состою & & 2 Не состою & & 0 \\
\hline 4 & & 4 Нет & & 0 не знаю & Состою & & 2 состою & & 2 \\
\hline 5 & & 5 Да, активный сейчас & & $22-$ & Состою & & 2 состоял(a) & & 1 \\
\hline 3 & & 3 Да, активный сейчас & & $22+$ & Состою & & 2 Не состою & & 0 \\
\hline
\end{tabular}

Figure 4 - Fragments of the spreadsheet with calculations 


\begin{tabular}{llllll} 
& ISRA (India) $=\mathbf{3 . 1 1 7}$ & SIS (USA) & $=\mathbf{0 . 9 1 2}$ & ICV (Poland) & $=\mathbf{6 . 6 3 0}$ \\
Impact Factor: & ISI (Dubai, UAE) $=\mathbf{0 . 8 2 9}$ & PUHL (Russia) $=\mathbf{0 . 1 5 6}$ & PIF (India) & $=\mathbf{1 . 9 4 0}$ \\
& GIF (Australia) $=\mathbf{0 . 5 6 4}$ & ESJI (KZ) & $=\mathbf{8 . 7 1 6}$ & IBI (India) & $=\mathbf{4 . 2 6 0}$ \\
& JIF & $\mathbf{1 . 5 0 0}$ & SJIF (Morocco) $=\mathbf{5 . 6 6 7}$ & OAJI (USA) & $\mathbf{0 . 3 5 0}$ \\
\hline
\end{tabular}

\section{Краткая история ваших кроводач}

И, наконец, самая важная информация! Постарайтесь, пожалуйста, вспомнить и ответить максимально честно. Это дейсвительно важно для результатов исследования.

Сколько лет Вы сдаете кровь? *

Не сдавал(а) ни разу

Менее полугода

От полугода до года

О 2 года

○ года

4 года

5 лет

6 лет и более

Сколько раз за это время Вы сдали кровь? *

В ответе укажите ТОЛЬКО ЦЕЛОЕ ЧИСЛО, без каких-либо пробелов и других символов. Если ни разу еще не сдавали кровь - введите ' 0 '.

Мой ответ

НАЗАД ОТПРАВИТЬ

Figure 3 - Donor information

The survey was conducted among students of St. Petersburg State Polytechnic University of absolutely different courses and student organizations.

\section{Analysis of collected data}

All results of the survey were collected in an Excel spreadsheet. Next to each answer column, we create another column that will convert students' answers into numerical results. For example, we had a question: "Gender with the variants "Male" and "Female". We create a column called "Gender" and ask the formula: $=\operatorname{IF}(\mathrm{B} 2="$ male"; $1 ; 0)$. This formula is particularly important to us because this number is used in the formula for calculating the percentage of donor activity as a component of $\mathrm{G}$.
The same goes for the rest of the answer columns, converting text results into numbers. We do the same with each student union. If a person chose the option of "standing", the number "2", "consisted of" - "1", "not standing" - "0" will appear in the next column. Then it was decided to calculate the total student activity, so we add the column "StudActivity" after all the associations and count the sum of the accumulated points.

Then, after the donor information, we make calculations using all the formulas described above and determine the final class of donor activity.

Let's imagine fragments of the spreadsheet with calculations (Figure 4).

Designing the dependency tree 


\begin{tabular}{|c|c|c|c|c|c|c|}
\hline \multirow{4}{*}{ Impact Factor: } & ISRA (India) & $=3.117$ & SIS (USA) & $=0.912$ & ICV (Poland) & $=6.630$ \\
\hline & ISI (Dubai, UAI & $=0.829$ & РИНЦ (Russia & $=0.156$ & PIF (India) & $=1.940$ \\
\hline & GIF (Australia) & $=0.564$ & ESJI (KZ) & $=8.716$ & IBI (India) & $=4.2 \mathrm{C}$ \\
\hline & JIF & $=1.500$ & SJIF (Morocec & $=5.667$ & OAJI (USA) & $=0.3$ \\
\hline
\end{tabular}

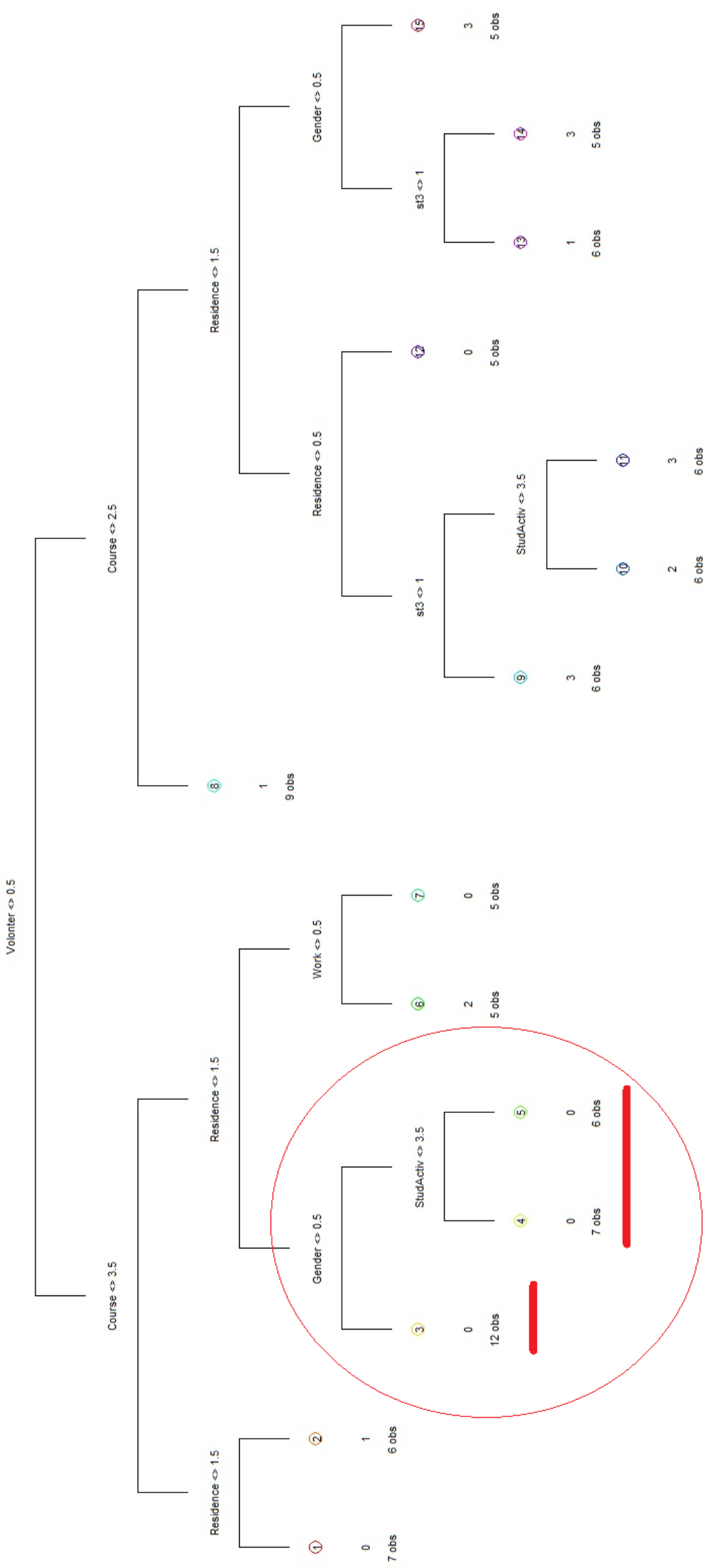

Figure 5 - Dependency tree 


\begin{tabular}{llllll} 
& ISRA (India) $=\mathbf{3 . 1 1 7}$ & SIS (USA) & $=\mathbf{0 . 9 1 2}$ & ICV (Poland) & $=\mathbf{6 . 6 3 0}$ \\
Impact Factor: & ISI (Dubai, UAE) $=\mathbf{0 . 8 2 9}$ & PUHL (Russia) $=\mathbf{0 . 1 5 6}$ & PIF (India) & $=\mathbf{1 . 9 4 0}$ \\
& GIF (Australia) $=\mathbf{0 . 5 6 4}$ & ESJI (KZ) & $=\mathbf{8 . 7 1 6}$ & IBI (India) & $=\mathbf{4 . 2 6 0}$ \\
& JIF & $\mathbf{1 . 5 0 0}$ & SJIF (Morocco) $=\mathbf{5 . 6 6 7}$ & OAJI (USA) & $\mathbf{0 . 3 5 0}$ \\
\hline
\end{tabular}

We will create a dependency tree model [7] in RStudio environment in $\mathrm{R}$ language. $\mathrm{R}$ is a powerful scripting language, focused on statistics. It is very convenient for data analysis and machine learning [8]. And RStudio is an integrated development environment (IDE) for R [9].

During the design process, a program was created that reads the data from the spreadsheet and selects the required columns. Then it builds a dependency tree, excluding our ActivityType donor activity classifier.

Here is the code of the dependency tree model:

\#install.packages("xlsx")

\#install.packages("tree")

\#install.packages("maptree")

library(xlsx)

library(tree)

library(maptree)

MyData<-

read.xlsx("C://Research//donors.xlsx",1)

MyData2<-

MyData[1:N,c("Gender","Work","Residence","Cours
e","Volonter","st1","st2", "st3", "st4", "st5", "st6", "st7", "st8", "st9", "st10", "st11", "st12", "st13", "st14", "st15", "st16", "st17", "st18","StudActiv", "ActivityType")]

MyData2\$Course<-

as.numeric(as.factor(MyData2\$Course))

MyData2\$ActivityType<-

as.factor(MyData2\$ActivityType)

bc.tr <- tree(ActivityType ., MyData2)

draw.tree(bc.tr, cex $=0.7$ )

bc.tr

This program has made the following tree of dependences (Figure 5).

However, the tree built is excessive. It can be optimized by "cutting off" the nodes, from where both branches lead to the same class [10]. In the figure, this part is highlighted in red circle and lines.

Code for tree optimization:

bc.tr1 <- snip.tree (bc.tr, nodes $=10)$

draw.tree(bc.tr1, cex $=0.7$ )

bc.tr1 


\begin{tabular}{llllll} 
& ISRA (India) $=\mathbf{3 . 1 1 7}$ & SIS (USA) $=\mathbf{0 . 9 1 2}$ & ICV (Poland) & $=\mathbf{6 . 6 3 0}$ \\
Impact Factor: & ISI (Dubai, UAE) $=\mathbf{0 . 8 2 9}$ & PUHL (Russia) $=\mathbf{0 . 1 5 6}$ & PIF (India) & $=\mathbf{1 . 9 4 0}$ \\
& GIF (Australia) $=\mathbf{0 . 5 6 4}$ & ESJI (KZ) & $\mathbf{8 . 7 1 6}$ & IBI (India) & $=\mathbf{4 . 2 6 0}$ \\
& JIF & $\mathbf{1 . 5 0 0}$ & SJIF (Morocco) $=\mathbf{5 . 6 6 7}$ & OAJI (USA) & $\mathbf{= 0 . 3 5 0}$ \\
\hline
\end{tabular}

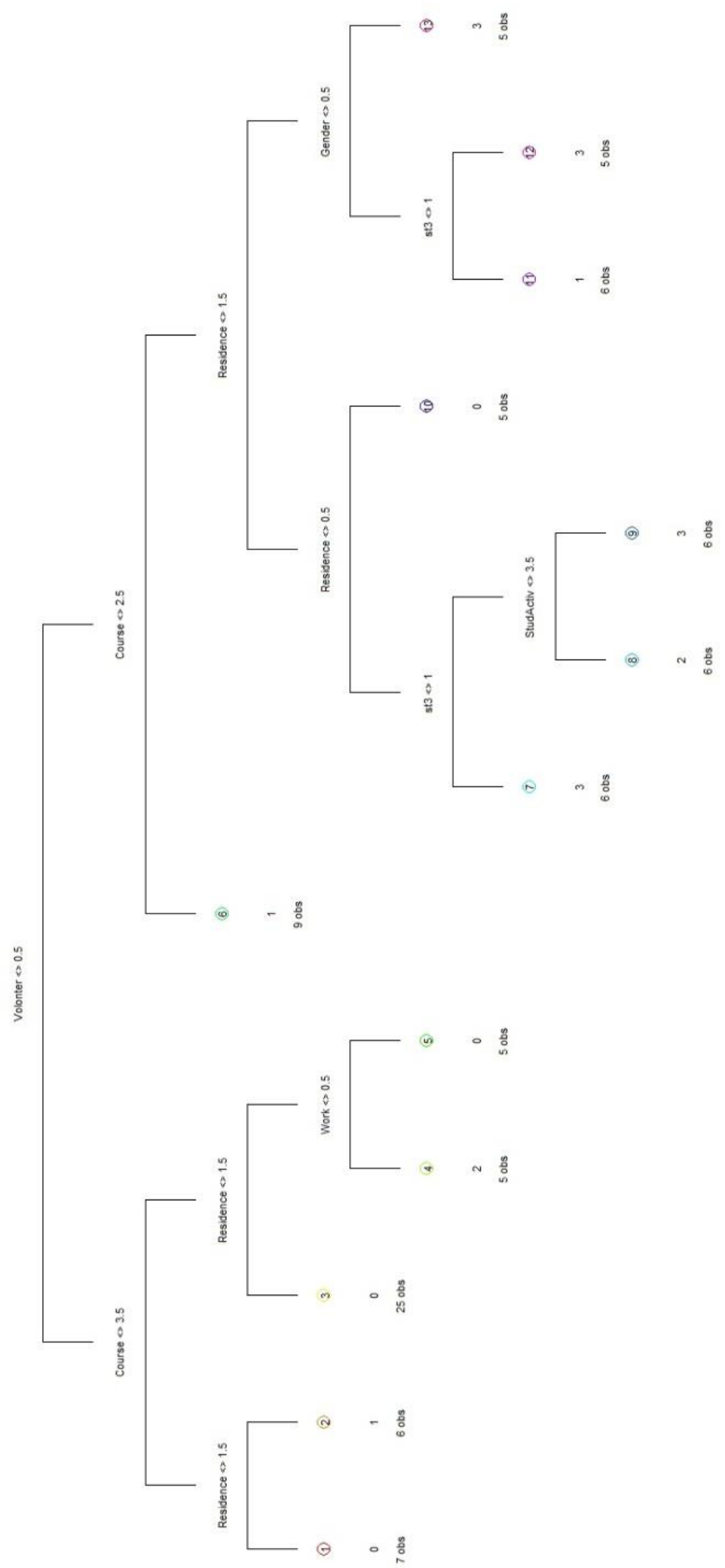




\begin{tabular}{llllll} 
& ISRA (India) $=\mathbf{3 . 1 1 7}$ & SIS (USA) & $=\mathbf{0 . 9 1 2}$ & ICV (Poland) & $=\mathbf{6 . 6 3 0}$ \\
Impact Factor: & ISI (Dubai, UAE) $=\mathbf{0 . 8 2 9}$ & PUHL (Russia) $=\mathbf{0 . 1 5 6}$ & PIF (India) & $=\mathbf{1 . 9 4 0}$ \\
& GIF (Australia) $=\mathbf{0 . 5 6 4}$ & ESJI (KZ) & $=\mathbf{8 . 7 1 6}$ & IBI (India) & $=\mathbf{4 . 2 6 0}$ \\
& JIF & $\mathbf{1 . 5 0 0}$ & SJIF (Morocco) $=\mathbf{5 . 6 6 7}$ & OAJI (USA) & $\mathbf{0 . 3 5 0}$ \\
\hline
\end{tabular}

You can see the tree after optimization at Figure

6.

Analysis of obtained dependencies and results from the dependency tree

In order to identify all the identified dependencies, we will walk through the tree and write the path. Before exploring the tree, we will discuss some of the signs and rules. For example, the top of the tree is the expression "Volonteer $<>0.5 "$. The values of the "Volonter" field can be from 0 to 2 . Correspondingly, this entry means that the branches on the left are composed for the values $<0.5$, that is, " 0 ", and the branches on the right are greater than 0.5 , that is, for "1" and "2" together. All expressions above the branches are made according to the same principle. The leaves of the tree are the activity class of the donor directly. You can see right away that there are no leaves with a value of "4", which means that there are no regular donors among the respondents.

Let's move on to the analysis of the tree. For convenience, let us remind you of the possible values of donor activity classes:

0 . Not the donor;

1. Inactive or novice donor;

2. Normal;

3. Active;

4. Permanent.

Next, only the numeric values of the donor classes will be used.

Let's start with the left side of the tree, i.e. the part where all students are not and were not volunteers of the "Donor Day" campaign. Then the branch is divided into 2 parts according to the course, and exactly: in the left half there is a 1-3 courses, and in the right 5-6. Thus, for students of the 1 st-3rd courses, living with relatives or renting an apartment, the type " 0 " was defined (and for those living in a dormitory "1"). The results can be explained by the fact that junior students could only recently learn about the campaign and come to it. However, there is already more activity among the students living in the dormitory than among the others.

The division between seniors and non-volunteers is a bit more difficult. However, the previous trend persists: students living with relatives or renting an apartment got the "0" type. Students living in a dormitory and having a job also received type " 0 ", and without a job - type "2". These results so far confirm the hypothesis of higher activity of dormitory residents, and also support our assumption that the work affects the activity of the donor rather negatively.

Now let's consider the right side of the tree - a separate investigation of people who are volunteers themselves or were once before. Here, the division by course is different and gives immediate results. Student volunteers from 1-2 courses have a class "1".
This can also be explained by the recent arrival and acquaintance with the campaign. The students of the older courses are divided by accommodation. On the right side of the tree, there are only dorm residents. For such students the following division has turned out: men have a class "3", female students who were taken part in student departments also have a class "3", and not in the student department- "1". Gender indicators can only be justified by the fact that men can donate blood once a year more than women. However, this factor has been taken into account in one of the class definition criteria. In addition, such reasoning is more relevant for Class "4", which we do not have.

Among the students living outside the dormitory, there is an even narrower division in terms of accommodation: those who rent an apartment or room received a " 0 " class. Further on, class " 3 " was received from students, who live with relatives and don't consist of student departments. The members of student groups were divided into 2 more groups: the guys with the total indicator of student activity: StudActiv $>=4$ also received a class " 3 ", with a lower total activity - "2". Let us remind you that the indicator of student activity is the total score for all student associations. These results correspond to our hypotheses about the relationship between student activity and donor activity. Even the assumption of the highest activity among student departments is partially confirmed. But it does not work in the opposite direction: high activity was also shown among students who are not take part in student departments.

So, we have considered the whole dependency tree and now we can sum up the results:

- Students living in a dormitory more often than not are more active as donors.

- Work, if it has any impact on donor activity, is negative.

- There is a high level of activity among students in student departments. However, among the non-members as well.

- General student activity also has a positive impact on donor activity.

- There are some gender addictions.

- Students in the more advanced courses were more active, namely, 3-6 courses.

- High activity is noticeable among the volunteers of the campaign.

\section{Development of a predictor model}

In order to check the correctness of the dependency tree it is necessary to create some model of machine learning.

Let's define the class of the problem for our research. The most popular ones are regression, clustering and classification tasks. In the regression 


\begin{tabular}{llllll} 
& ISRA (India) $=\mathbf{3 . 1 1 7}$ & SIS (USA) & $=\mathbf{0 . 9 1 2}$ & ICV (Poland) & $=\mathbf{6 . 6 3 0}$ \\
Impact Factor: & ISI (Dubai, UAE) $=\mathbf{0 . 8 2 9}$ & PUHL (Russia) $=\mathbf{0 . 1 5 6}$ & PIF (India) & $=\mathbf{1 . 9 4 0}$ \\
& GIF (Australia) $=\mathbf{0 . 5 6 4}$ & ESJI (KZ) & $=\mathbf{8 . 7 1 6}$ & IBI (India) & $=\mathbf{4 . 2 6 0}$ \\
& JIF & $\mathbf{1 . 5 0 0}$ & SJIF (Morocco) $=\mathbf{5 . 6 6 7}$ & OAJI (USA) & $\mathbf{0 . 3 5 0}$ \\
\hline
\end{tabular}

tasks, the real answer is predicted on the basis of different ones, and clustering tasks are the division of data into similar categories. Our task belongs to the classification class: on the basis of various factors we will assign a categorical answer.

Most of the machine learning tasks can be divided into supervised learning and unsupervised learning. What is the difference between them? It's very simple: in teacher training we have the data and some dependency to predict the appearance of any result; in teacherless training we only have the data [11].

Our model uses teacher-assisted instruction because there are collected data and calculated criteria for the training sample, which are then used as a donor activity class in the test sample. In the learning sample, the model learns and determines the dependencies between the data and the class of predictions, in the test sample the model already uses the dependencies obtained and predicts the class.

For predictions we will use the naive Bayesian classifier, because it is one of the most popular and simple solutions for creating predictions.

The naive Bayesian classifier can be of 3 types: Multinomial Naive Bayes, Bernoulli Naive Bayes and Gaussian Naive Bayes.

Bernoulli Naive Bayes could be used if all our features would be Boolean functions and would matter only to yes" or "no". However, our study is much more complex and the signs are not as simple.

Gaussian Naive Bayes is suitable for continuous and non-continuous values. In our case, this is not necessary, because all the signs will be represented only by integers.

What remains is Multinomial Naive Bayes, which is designed for data that can be easily converted into calculations. In our study, all the information is presented in this way [12].

In total, we use Multinomial Naive Bayes to divide the data we have collected into 2 parts programmatically: $70 \%$ is a training sample (for model training), $30 \%$ is a test sample, and we will see the results of the classifier's work using it.

Classifier code:

set.seed(12345)

$\mathrm{n}<-\operatorname{dim}($ MyData2)[1]

data_rand <- MyData2[ order(runif(n)), ]

nt $<-$ as.integer $\left(\mathrm{n}^{*} 0.7\right)$

data_train <- data_rand[1:nt, ]

data_test $<$ - data_rand[(nt+1):n, ]

donor_tree $<$ - tree(ActivityType .,data_train)

prediction <- predict(donor_tree, newdata $=$ data_test,type $=$ "class")

confMat <- table(prediction, data_test\$ActivityType)
print(confMat)

accuracy <- sum(diag(confMat))/sum(confMat)

print(paste0("Accuracy: ", accuracy))

Work results:

$\begin{array}{rlllll}\text { prediction } & 0 & 1 & 2 & 3 & 4 \\ 0 & 7 & 2 & 4 & 1 & 0 \\ 1 & 0 & 0 & 0 & 2 & 0 \\ 2 & 0 & 1 & 1 & 2 & 0 \\ 3 & 0 & 1 & 0 & 5 & 3 \\ 4 & 0 & 0 & 0 & 0 & 0\end{array}$

Let's see what these results mean and how to read such a table correctly.

Top and left are class markers: 01234 . Those above are the real values of the classifier class. Those on the left are how many values are predicted. That is, we look at class " 0 " from above: 7 values of all in this class and all were predicted in class 0 . Now we see on the left: class " 0 " also contains 2 more values from class "1", 4 values of class "2", 1 value of class "3" and zero value of class " 4 ".

We see that the results are far from ideal. In order to call the work of the classifier good in this table all the numbers should be located only on the main diagonal. Since the numbers of the main diagonal are just the number of values defined correctly in their class. All other values should be zeros.

The classifier also considers the accuracy of the results on its own. We received the donor activity classifier with an accuracy of about $45 \%$.

\section{[1] "Accuracy: 0.448275862068966"}

Unfortunately, this is not a very good result. The accuracy of the classifier is less than $50 \%$, which means that the detected dependencies are not completely correct.

\section{Results of the research}

We will sum up the general results of the study. In the course of the work, indicators and criteria for determining the class of donor activity were developed, and data were collected and analyzed. A dependency tree was also obtained, and the classifier model was trained and tested.

Unfortunately, the predictor gives too little accuracy. This may be due to the lack of dependencies we have presented or to a lack of training of the model, i.e. lack of data for analysis. The "Donor Day" campaign plans to continue the research and collect more data to make a final decision about the existence of dependencies.

According to the considered tree of dependencies, we can say that most of the hypotheses were justified. However, the following facts became unexpected:

- High activity was noticed among seniors;

- There's a slight gender dependency; 


\begin{tabular}{llllll} 
& ISRA (India) $=\mathbf{3 . 1 1 7}$ & SIS (USA) & $=\mathbf{0 . 9 1 2}$ & ICV (Poland) & $=\mathbf{6 . 6 3 0}$ \\
Impact Factor: & ISI (Dubai, UAE) $=\mathbf{0 . 8 2 9}$ & PUHL (Russia) $=\mathbf{0 . 1 5 6}$ & PIF (India) & $=\mathbf{1 . 9 4 0}$ \\
& GIF (Australia) $=\mathbf{0 . 5 6 4}$ & ESJI (KZ) & $=\mathbf{8 . 7 1 6}$ & IBI (India) & $=\mathbf{4 . 2 6 0}$ \\
& JIF & $\mathbf{1 . 5 0 0}$ & SJIF (Morocco) $=\mathbf{5 . 6 6 7}$ & OAJI (USA) & $\mathbf{0 . 3 5 0}$ \\
\hline
\end{tabular}

- Donor activity among adapters not noticed.

In total, we have a tree of dependencies similar to the hypotheses advanced and a predictor classifier with little accuracy to be able to predict the donor activity class at this stage.

\section{Conclusion}

So, all the tasks were performed of the research. Dependences from the tree of dependences are almost completely to the hypotheses put forward before the work. The results of the classifier's predictions are ambiguous. Further it is planned to collect additional data and continue this research.

\section{References:}

1. (n.d.). "World blood donor day," [Online]. Retrieved June 15, 2019, from https://www.who.int/campaigns/world-blooddonor-day

2. (n.d.). "Donor Day," [Online]. Retrieved June 15, 2019, from https://donor.spb.ru/

3. Roth, W. K. (2010, June). "Quarantine Plasma: Quo vadis?," Transfus Med Hemother, pp. 118122.

4. (n.d.). "Student association," [Online]. Retrieved June 15, 2019, from https://www.spbstu.ru/student-association

5. (n.d.). "Donor Day. About," [Online]. Retrieved June 15, 2019, from https://donor.spb.ru/about/

6. (n.d.). "How often can you donate blood?," [Online]. Retrieved June 15, 2019, from https://podari-zhizn.ru/main/node/6969

7. (n.d.). "R: Data analysis and visualization," [Online]. Retrieved June 15, 2019, from https://r-analytics.blogspot.com/2017/02/blogpost.html\#.XQhJuIj7ShM
8. (n.d.). "Do I need to learn R?," [Online]. Retrieved June 15, 2019, from https://www.ibm.com/developerworks/opensour ce/library/bd-

learnr/index.html?S_TACT=105AGX99\&S_C $\underline{\mathrm{MP}}$

9. (n.d.). "Rstudio," [Online]. Retrieved June 15, 2019 , from https://www.rstudio.com/products/RStudio

10. (n.d.). "Tree-Based Optimization: A MetaAlgorithm for Metaheuristic Optimization," [Online]. Retrieved June 15, 2019, from https://arxiv.org/pdf/1809.09284.pdf

11. (n.d.). "Machine learning novice," [Online]. Retrieved June 15, 2019, from https://newtonew.com/tech/machine-learningnovice

12. (n.d.). "Naive Bayes Classifier," [Online]. Retrieved June 15, 2019, from https://towardsdatascience.com/naive-bayesclassifier-81d512f50a7c 